\title{
PRE-ANAESTHETIC MEDICATION IN PAEDIATRIC DAY-CARE SURGERY*
}

\author{
Robert Desjardins, Samir Ansara and Jean Charest
}

\begin{abstract}
Pre-anaesthetic medication has the primary aim of making the whole process of anaesthesia smooth and agreeable. This prospective blind study was planned to compare the efficacy of three active drugs and a placebo as premedication in a paediatric population undergoing operation on a day care basis.

One hundred and fifty-nine patients between one and 12 years of age were assigned randomly to one of four groups who received either hydroxyzine $0.5 \mathrm{mg} \cdot \mathrm{kg}^{-1}(\mathrm{n}-43)$ promethazine $0.5 \mathrm{mg} \cdot \mathrm{kg}^{-1}(\mathrm{n} 40)$ diazepam $0.1 \mathrm{mg} \cdot \mathrm{kg}(\mathrm{n}-37)$ or placebo $(\mathrm{n}-36)$ by mouth, 60 minutes before operation. Observations in the operating room included the emotional state of the patient on arrival, qualit; of induction and complications. In the recovery room time for emergence from anaesthesia, complications and requirements for analgesia were recorded. The parents were asked to return a questionnaire detailing psychological and physical complications during the three postoperative days.

There was no difference between the groups in any of the factors examined. From this study we conclude that children undergoing surgical operations and anaesthesia on a day care basis should not receive pharmacological premedication, not because of overwhelming risk from its use, but because of the absence of any benefit.
\end{abstract}

Key Words: Premedication, paediatric day-care surgery

Pre-Ananaesthetic medication is a widely debated issue. Forty years after Ralph Waters advocated the use of intramuscular morphine and scopolamine to sedate children before anaesthesia ${ }^{1}$ there is no unanimity about the aim of premedication, route of administration, or the best pharmacological agents. There appears to be unanimity among anaesthetists that adults undergoing anaesthesia on a day care basis are better without premedication, because the ideal agent which will make patients calm and serene before operation without unduly delaying the recovery period does not exist. ${ }^{2}$ Furthermore, adults often do not follow instructions and restrictions in the post-operative period. ${ }^{3.4}$ If the risks from premedication exceed the benefits in the adult population, is the same true for children?

In an attempt to answer this question we undertook a double blind study to evaluate the physical and psychological complications associated with pre-anaesthetic medication and to

Robert Desjardins, M.D., Resident In Anaesthesia; Samir Ansara, M.D., F.R.C.P. (C)., Assistant Professor; Jean Charest, M.D., F.R.C.P. (C)., Assistant Professor and Director, Department of Anaethesia, Hôpital Ste. Justine; Universite de Montréal, Montreal, Quebec.

Reprint requests to Dr. S. Ansara.

* Presented at the Annual Meeting, Canadian Anaesthetists' Society, Toronto, Ontario. June 23, 1980.

Canad. Anaesth. Soc. J., vol. 28, no. 2, March 1981 determine whether the premedications used are helpful in smoothing induction of anaesthesia in children undergoing surgical operations on a day care basis.

\section{Patients and Methods}

Each morning the anaesthetists and a recovery room nurse selected a few patients at random from the day surgery list to be entered into the study. All patients were ASA status I or II, and their ages ranged from one to twelve years. The parents and the child were visited and the aim, protocol, risks and benefits of the study were explained. Informed consent was signed by the parents.

After selection a card was completed for each patient with a record of name, home address, age, weight, allergies if present and the type of operation planned. This card was sent to the hospital's pharmacist, who assigned each patient at random to one of four therapeutic groups for each type of surgery planned. This method permitted an equal distribution of types of surgery in each therapeutic group. The therapeutic groups were based on the premedication to be given as follows:

Group 1 - hydroxyzine $0.5 \mathrm{mg} \cdot \mathrm{kg}^{-1}$

Group 2 - promethazine $0.5 \mathrm{mg} \cdot \mathrm{kg}^{-1}$

Group 3 - diazepam $0.1 \mathrm{mg} \cdot \mathrm{kg}^{-1}$

Group 4 - placebo. 
TABLE I

ANAESTHETISTS' OBSERVATIONS

\begin{tabular}{|c|c|c|c|c|c|}
\hline \multirow[b]{2}{*}{ Observations } & \multirow[b]{2}{*}{ Values } & \multicolumn{4}{|c|}{ Therapeutic groups } \\
\hline & & $\begin{array}{l}\text { Hydroxyzine } \\
\text { (43 patients) }\end{array}$ & $\begin{array}{l}\text { Promethazine } \\
\text { (40 patients) }\end{array}$ & $\begin{array}{c}\text { Diazepam } \\
\text { (37 patients) }\end{array}$ & $\begin{array}{c}\text { Placebo } \\
\text { (36 patients) }\end{array}$ \\
\hline $\begin{array}{l}\text { Emotional state on } \\
\text { arrival in the } \\
\text { operating room }\end{array}$ & $\begin{array}{l}\text { Serene } \\
\text { Apprehensive } \\
\text { Moderately anxious } \\
\text { Extremely anxious }\end{array}$ & $\begin{array}{c}86 \% \\
7 \\
5 \\
2\end{array}$ & $\begin{array}{l}72 \% \\
13 \\
10 \\
5\end{array}$ & $\begin{array}{l}75 \% \\
20 \\
5 \\
0\end{array}$ & $\begin{array}{l}58 \% \\
28 \\
8 \\
6\end{array}$ \\
\hline Quality of induction & $\begin{array}{l}\text { Smooth } \\
\text { Adequate } \\
\text { Moderately agitated } \\
\text { Agitated } \\
\text { Stormy }\end{array}$ & $\begin{array}{l}58 \% \\
12 \\
16 \\
12 \\
2\end{array}$ & $\begin{array}{l}40 \% \\
25 \\
15 \\
15 \\
5\end{array}$ & $\begin{array}{l}60 \% \\
22 \\
8 \\
8 \\
2\end{array}$ & $\begin{array}{l}36 \% \\
30 \\
25 \\
6 \\
3\end{array}$ \\
\hline $\begin{array}{l}\text { Satisfaction with the } \\
\text { premedication } \\
\text { received }\end{array}$ & $\begin{array}{l}\text { Excellent } \\
\text { Very good } \\
\text { Good } \\
\text { Poor } \\
\text { Unacceptable }\end{array}$ & $\begin{array}{l}33 \% \\
26 \\
21 \\
12 \\
8\end{array}$ & $\begin{array}{l}23 \% \\
25 \\
25 \\
20 \\
7\end{array}$ & $\begin{array}{l}28 \% \\
33 \\
19 \\
11 \\
9\end{array}$ & $\begin{array}{l}17 \% \\
22 \\
47 \\
11 \\
3\end{array}$ \\
\hline $\begin{array}{c}\text { Complications } \\
\text { observed }\end{array}$ & $\begin{array}{l}\text { Bradycardia } \\
\text { Tachycardia } \\
\text { Cardiac arrythmias } \\
\text { Laryngospasm } \\
\text { Bronchospasm } \\
\text { Bronchorrhea } \\
\text { Sialorrhea } \\
\text { Apnea }\end{array}$ & $\begin{array}{c}23 \% \\
7 \\
7 \\
2 \\
2 \\
2 \\
26 \\
0\end{array}$ & $\begin{array}{c}15 \% \\
3 \\
15 \\
3 \\
0 \\
3 \\
10 \\
0\end{array}$ & $\begin{array}{l}5 \% \\
5 \\
5 \\
0 \\
0 \\
3 \\
11 \\
3\end{array}$ & $\begin{array}{l}6 \% \\
3 \\
6 \\
3 \\
0 \\
6 \\
20 \\
3\end{array}$ \\
\hline
\end{tabular}

TABLE II

Recovery Room Nurse's ObServations

\begin{tabular}{|c|c|c|c|c|c|}
\hline \multirow[b]{2}{*}{ Observations } & \multirow[b]{2}{*}{ Values } & \multicolumn{4}{|c|}{ Therapeutic groups } \\
\hline & & $\begin{array}{l}\text { Hydroxyzine } \\
\text { (42 patients) }\end{array}$ & $\begin{array}{l}\text { Promethazine } \\
\text { (38 patients) }\end{array}$ & $\begin{array}{c}\text { Diazepam } \\
\text { (35 patients) }\end{array}$ & $\begin{array}{l}\text { Placebo } \\
\text { (35 patients) }\end{array}$ \\
\hline $\begin{array}{l}\text { Time delay for } \\
\text { gross emergence }\end{array}$ & $\begin{array}{l}\text { Mean time (minutes) } \\
\text { Standard deviation }\end{array}$ & $\begin{array}{l}22.3 \\
12.6\end{array}$ & $\begin{array}{l}23.4 \\
14.7\end{array}$ & $\begin{array}{l}23.1 \\
15.9\end{array}$ & $\begin{array}{l}25.5 \\
13.4\end{array}$ \\
\hline $\begin{array}{l}\text { Time delay for } \\
\text { verbal response }\end{array}$ & $\begin{array}{l}\text { Mean time (minutes) } \\
\text { Standard deviation }\end{array}$ & $\begin{array}{l}29.3 \\
13.4\end{array}$ & $\begin{array}{l}34.6 \\
19.7\end{array}$ & $\begin{array}{l}33.7 \\
15.9\end{array}$ & $\begin{array}{l}32.2 \\
13.5\end{array}$ \\
\hline $\begin{array}{l}\text { Total duration of } \\
\text { recovery room stay }\end{array}$ & $\begin{array}{l}\text { Mean time (minutes) } \\
\text { Standard deviation }\end{array}$ & $\begin{array}{l}43.1 \\
18.9\end{array}$ & $\begin{array}{l}48.3 \\
18.4\end{array}$ & $\begin{array}{l}43.1 \\
17.6\end{array}$ & $\begin{array}{l}44.9 \\
18.0\end{array}$ \\
\hline $\begin{array}{l}\text { Complications } \\
\text { observed }\end{array}$ & $\begin{array}{l}\text { Bradycardia } \\
\text { Tachycardia } \\
\text { Cough } \\
\text { Inspiratory noise } \\
\text { Hypertension } \\
\text { Hypotension } \\
\text { Nausea and vomiting } \\
\text { Sore throat } \\
\text { Headache } \\
\text { Confusion }\end{array}$ & $\begin{array}{l}0 \% \\
2 \\
2 \\
0 \\
0 \\
0 \\
2 \\
7 \\
0 \\
2\end{array}$ & $\begin{array}{l}0 \% \\
0 \\
2 \\
2 \\
7 \\
0 \\
12 \\
10 \\
0 \\
10\end{array}$ & $\begin{array}{l}0 \% \\
3 \\
3 \\
0 \\
3 \\
0 \\
9 \\
3 \\
0 \\
3\end{array}$ & $\begin{array}{l}0 \% \\
5 \\
0 \\
0 \\
0 \\
0 \\
3 \\
11 \\
3 \\
3\end{array}$ \\
\hline Need for analgesia & $\begin{array}{l}\text { Nil } \\
\text { Meperidine } 1 \mathrm{mg} \cdot \mathrm{kg}^{-1} \mathrm{IM}\end{array}$ & $\begin{array}{l}70 \% \\
30\end{array}$ & $\begin{array}{l}60 \% \\
40\end{array}$ & $\begin{array}{l}77 \% \\
23\end{array}$ & $\begin{array}{l}70 \% \\
30\end{array}$ \\
\hline
\end{tabular}


TABLE III

Parent's Observations

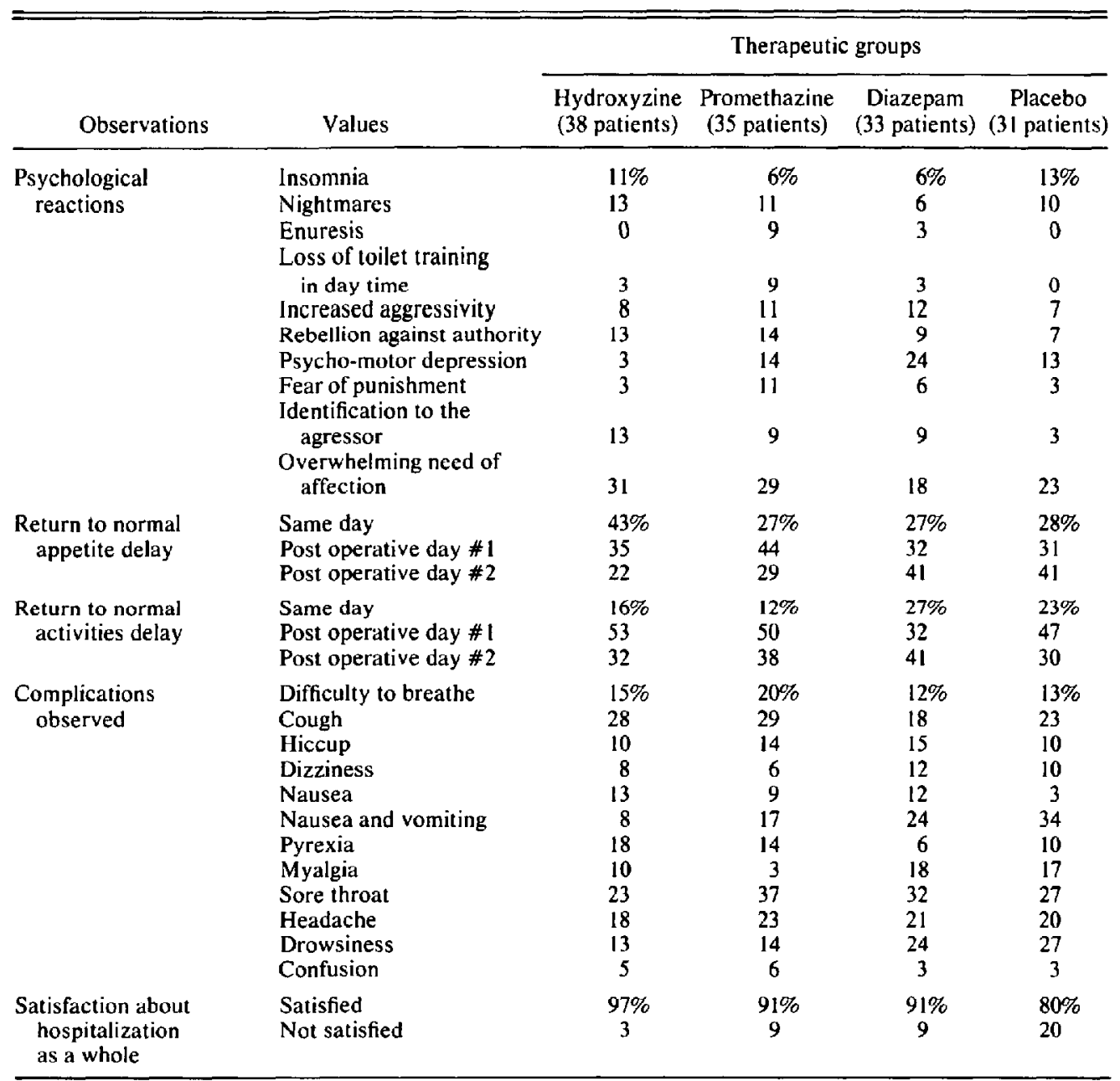

The premedication was prepared in elixir form, standardized for volume, but not for taste or colour. The premedication was sent to the unit, identified only by the name of the patient and accompanied by a sealed envelope containing the identification and dose of the agent used. This envelope was kept with the patient's chart, to be opened in any emergency situation. The premedication was administered by mouth about 60 minutes before induction of anaesthesia.

In the operating room the anaesthetists answered the series of questions set out in Table I. In the recovery room the nurse recorded answers to the questions set out in Table II. After discharge from the recovery room the child was kept under observation in his room for about five hours before going home. The parents were given a questionnaire (Table III) to be answered and returned by mail to the Department on the third post-operative day.

For statistical analysis of yes or no answers we employed a chi-square test; for ordinal scale values a log-linear analysis of ordinal qualitative data by the method of maximum likelihoods (Figure 1); for time values a Student $t$ test was used when only two groups were compared and a one way analysis of variance with Scheffe simple contrasts when more than two groups were compared. $\mathrm{P}<0.05$ was considered significant.

\section{Results}

Our study included 159 patients. The parents' questionnaire was returned by 137 families - an 


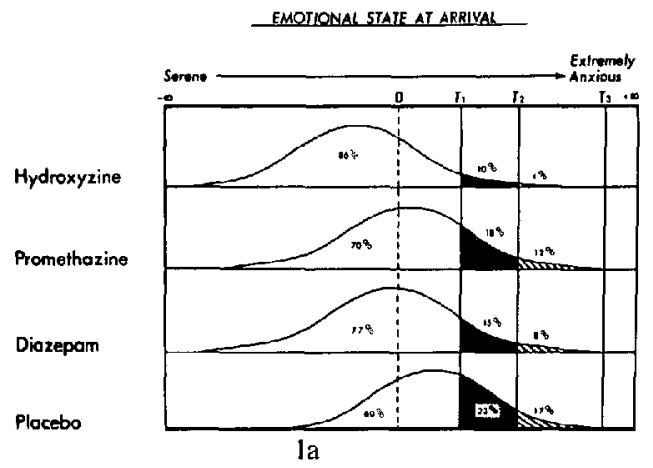

QUALIT OF NOUKWION

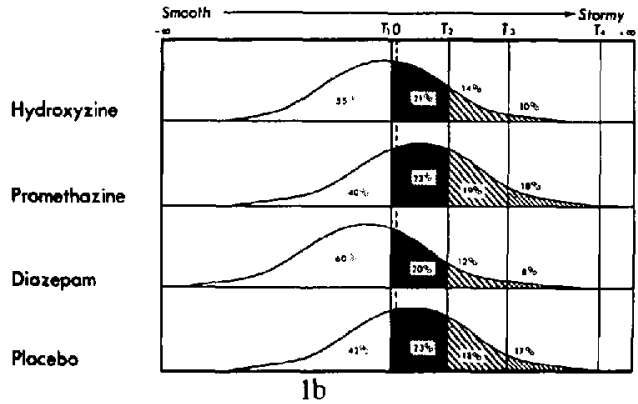

SATISFACTION OF PREMEDICATION

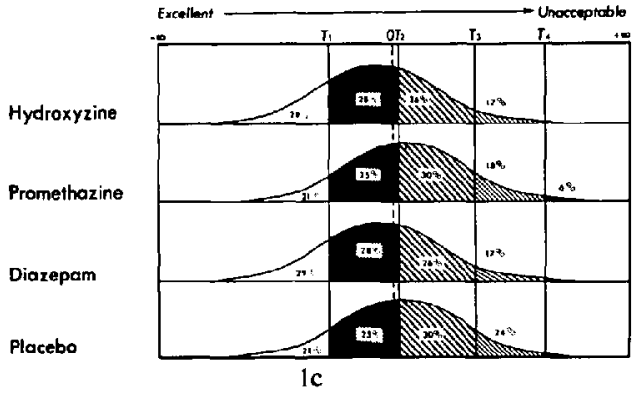

FIGURE I This figure illustrates the application of a log-linear analysis of ordinal qualitative data by the method of maximum likelihood to (a) the evaluation by the anaesthetist of the emotional status of children on their arrival in the operating room, (b) the anaesthetists' appreciation of the quality of induction of anaesthesia (c) the overall satisfaction of the anaesthetists for each of the four therapeutic groups. Curves represent the frequency of responses standardized for one hundred patients against the linear representation (by opposition to the compartmental one) of the qualitative data studied. By comparing area under curves between thresholds, one can determine a chi square test. The similarity of shape of the curves in each therapeutic groups is proof that anaesthetists have applied the same scale of values to all the groups and confirms the validity of the double blind technique. The analysis illustrated for three qualitative data were applied to all of them in the same way. answering rate of 86 per cent. It was never necessary to open the sealed envelope and no patient required over-night hospitalization.

The four therapeutic groups were similar in the following respects:-

- age of patients: - average age 5.2 years

- induction technique: 73 per cent with intravenous thiopentone and 27 per cent by an inhalational method

- use of anticholinergic drugs: 39 per cent received atropine $0.02 \mathrm{mg} \cdot \mathrm{kg}^{-1}$ intravenously at induction.

- use of neuromuscular blocking agents: 31 per cent.

\section{Anaesthetists' Observations (Table I)}

There was no significant difference between the four groups in the quality of induction or the anaesthetists' satisfaction with the premedication. For the emotional state of the child on arrival in the operating room there was no difference between the promethozine, diazepam and placebo groups, but the hydroxyzine group was significantly more calm than the placebo group (Figure 1). This advantage of hydroxyzine over placebo disappeared on induction of anaesthesia.

The incidence of complications was not significantly different in the four groups. Only 14 important complications were recorded - five arrhythmias, one prolonged apnoea and eight bronchorrhea or sialorrhea (of which the majority did not receive atropine at induction).

\section{Recovery Room Nurse Observations (Table II)}

There was no statistical difference between the four groups for time for gross emergence, verbal response or total stay in the recovery room. Complications were rare and of no major significance. Requirement for analgesia (meperidine $1 \mathrm{mg} \cdot \mathrm{kg}^{-1}$ instramuscularly) was not significantly different between the four groups.

\section{Parents' Observations (Table III)}

There was no significant difference between the four groups in post-operative psychological reactions (see Table III). Both normal appetite and activity returned on the second postoperative day. The complications reported by parents were equally distributed between the four groups. One or more of these complications could be reported in the same questionnaire and their degree ranged from mild to severe. Twenty-two questionnaires reported severe complaints which were equally distributed in the groups, these being four cases of drowsiness; one case of difficult breathing without other explanation from the parents; three cases of severe cough; one high 
temperature; four cases of headache; eight sore throats; one myalgia. However 90 per cent of parents were satisfied and would choose a day care unit again if another operation was needed.

\section{Miscellaneous}

Independently of the therapeutic groups, gross emergence delay and total stay in the recovery room were significantly longer in those patients who were induced with thiopentone $5 \mathrm{mg} \cdot \mathrm{kg}^{-1}$ intravenously than the inhalational induction group (25 minutes vs 19 minutes for gross emergence and 47 minutes vs 41 minutes for total stay). The incidence of physical and psychological complications were the same in hospital and at home for these two subgroups.

There was also a statistical difference between patients who had anaesthesia maintained with enflurane and halothane compared to those with methoxyflurane for delay of verbal response in the recovery room $(28,31$ and 44 minutes respectively) and total stay in the recovery room $(40,43$ and 59 minutes). There was no relation between anaesthetic agent used and the incidence of postoperative complications.

We observed a tendency for younger patients to have a stormy induction while the older group had a smoother induction, the stormy group having a mean age of 3.4 years compared to 6.0 years for the smoother group. There was no relation between a stormy induction and prolonged stay in the recovery room nor with a higher incidence of physical or psychological complications.

We observed a direct and significant relationship between the emotional state of the child on arrival in the operating room and the incidence of depressive behaviour postoperatively at home; however, there is no relation between the emotional state on arrival and the other psychological reactions reported.

\section{Discussion}

In the early days of the specialty premedication was given for security purposes. ${ }^{6.7}$ Since then anaesthetic agents and induction techniques have changed so much that the premedication very often is given by tradition rather than on a rational basis, ${ }^{8}$ except for anticholinergic drugs in the paediatric population to protect the patient against vagal reflexes. ${ }^{9.10}$ The widely accepted goal for premedication now is to make the experience of anaesthesia and surgery less disagreeable and less traumatic. ${ }^{6,7,11-14}$ That point of view changes the balance between the risks and benefits of premedication. In the adult population in day care surgery the question of premedication was settled after the reports of $\mathrm{Ogg}^{3}$ and Mailins; ${ }^{4}$ but for the paediatric population there is still no definite answer.

In 1945 Levy ${ }^{15}$ mentioned, for the first time, the negative effects of a traumatic experience of hospitalization and surgery on the psychological development of the child. Since then the subject has stimulated a host of authors, ${ }^{16-21}$ but we are still unable to answer the question - "should we give premedication to children undergoing day care surgery?' In an effort to answer this question, we have to establish the risk/benefit ratio for each patient; ${ }^{22}$ but to draw guidelines we decided to make the evaluation on a group which we think is representative of the general population having operations on a day care basis. In selecting drugs for premedication in this study we discarded the hypnotics (e.g. barbiturates) because of their unduly long half life and duration of action, ${ }^{2,23.24 .27}$ even though they are believed to provide effective premedication. ${ }^{25,26} \mathrm{We}$ also discarded the opiates despite the qualities attributed to them ${ }^{25}$ because of the reported high incidence of postoperative complications, even with fentanyl. ${ }^{28-31}$ Of the major tranquilizers, promethazine was chosen because of its well known sedative and antiemetic properties ${ }^{32}$ and low incidence of complications. Diazepam was chosen to represent the minor tranquilizer group. With its half life of 20 to 40 hours, ${ }^{33}$ diazepam is less interesting than oxazepam, with a half life of 2-3 hours, but the latter is not yet available in an elixir form. We used diazepam in low dose because Korttila ${ }^{35}$ has shown that it has little influence on psychomotor tests after six hours. Finally, the antihistamanic hydroxyzine was choosen because of its good sedating effect and its duration of action of about four to six hours. This choice of premedication agents is obviously arbitrary; we excluded all agents with moderate risks of complications because it was very important to be secure, especially in view of all the literature advising against premedication of adults submitted to day care surgery and anaesthesia. This is also the reason for choosing the posology of drugs in the low range of therapeutic dosages. Even though psychotherapy has been advocated as good premedication in adults ${ }^{36,37}$ and in children ${ }^{2,16,17,21,38-40}$ we deliberately ignored it to concentrate on the pharmacological premedications, which are more debatable.

For qualitative data we had to use external subjective evaluation, even if it is associated with an error of about 20 per cent, as pointed out by Nisbet and Norris. ${ }^{43}$ Although it is difficult to 
grade anxiety, pain, sedation or fear quantitatively, it is possible in an adult population to ask the patient. This is almost impossible with children. As an alternative, evaluating the patient's attitude toward his environment is generally a good reflection of his feelings: ${ }^{3,42}$ but we have to realize that drugs can sometimes modify the expression of feelings more than the feelings themselves. ${ }^{34,41}$ Finally for a recovery scale, we think Korttila's is excellent; ${ }^{35,54}$ but because some tests are impossible in children (flicker fusion test, tridimensional vision, driving simulator, etc. ...) we decided to adopt a very clinical and a bit imprecise gradation of the recovery period. The so-called gross emergence is the beginning of active mobilisation of the patient, the verbal response delay is the time necessary to establish verbal contact with the patient and the total stay duration is determined by a release decision based on at least 45 minutes of normal and stable vital signs and good orientation in space and persons.

The premedication we used, in the doses described and the mode and time of administration, were not better than placebo in bringing a calm and cooperative child for the induction of anaesthesia. However the anaesthetists' satisfaction ratio was about 80 per cent and this sustains Smith's conclusion' that any premedication administered will bring a satisfaction ratio of 60 to 70 per cent. Active drugs were not better than placebo in preventing psychological reactions postoperatively. The stormy type of induction was not associated with more frequent psychological reactions; this particular observation does not go along with Levy's conclusion or that of Francis, et al " $^{\text {T }}$ that a stormy induction of anaesthesia influences further psychological development of the child. Of course our study was restricted to the first three post-operative days and we cannot conclude the long term effects of this; but the immediate postoperative period was identical in the four therapeutic groups and in the stormy vs smooth induction groups. This could reinforce the hypothesis of Myers ${ }^{21}$ and Vernon ${ }^{48}$ that hospitalization alone could be mostly responsible for the psychic trauma observed, even in outpatient hospitalization. If we assume the separation from parents to have a traumatic effect on the child, the presence of one of the parents during induction of anaesthesia could theoretically reduce the trauma; but in practice it is difficult and of no great value.$^{23,25.45}$.

The incidence and severity of complications noted in this study are equally distributed be- tween the four therapeutic groups, so we can say that we did no harm or good to these children by premedicating them. The frequency of physical complications is comparable to other studies on day care surgery in children. ${ }^{45.46}$ As in previous studies, we noted a lower frequency of complications compared to outpatient surgery in adults. ${ }^{48-52}$ We explain that by the fact that children's complaints are reported indirectly and this makes reports a lot less accurate.

In our study, we did not find any relationship between a bad quality (or stormy) induction and prolonged recovery, as reported by Schmidt, et al. ${ }^{27}$ We did not observe a significant difference between the four groups in duration of stay in the recovery room; and we did show a prolonged recovery time in patients induced with barbiturates, as shown before. ${ }^{31,35,46}$

\section{Conclusions}

- Premedication used, in dosage and timing of administration used, were not better than placebo to ease induction of anaesthesia or to protect against psychological reactions in the first three postoperative days.

- Premedications used did not increase the incidence of physical complications during and after anaesthesia when compared with placebo.

- Stormy induction of anaesthesia is not associated with an increase in incidence of psychological reactions in the first three postoperative days nor with prolongation of the recovery period.

- Considering the absence of beneficial effect of the premedication used, even with no accentuated risks, we believe that children undergoing operating on a day care basis should not receive pharmacologic premedication; if the anaesthetist decides to give some, as a personal decision, it can be done without undue risk.

\section{REFERENCES}

1. Sмith, R.M. Pediatric anesthesia in perspective. Anesth. Analg. 57: 634-646 (1978).

2. COBB, M.L. \& StePHeN, C.R. Role of premedication in out patient anesthesia. Contemporary Anesthesia Practice 1: 31-42 (1978).

3. OGG, T.W. An assessment of postoperative out patient cases. Brit. Med. J. 4:573 (1972).

4. MALINS, A.F. Do they do as they are instructed? A review of out patient anaesthesia. Anaesthesia 33: 832-835 (1978).

5. Bock, R.D. Multivariate statistical methods in behavioral research. New York. McGraw-Hill (1975) from McGraw-Hill series in Psychology.

6. OMINSKY, A.J. Preanesthetic medication: an ob- 
solete practice. Annual Refresher Course Lectures of ASA. Course 123 (1978).

7. OMINSKY, A.J. Premedication in the anxious patient. Annual Refresher Course Lectures of ASA. Course 131 (1979).

8. Premedication tradition. Lancet 1066 (1977).

9. STEward, D.J. Premedication for the pediatric patient. Annual Refresher Course Lectures of ASA. Course 101 (1979).

10. Collins, V.J. Principles of Anesthesiology. Second ed. pp. 210-224. Lea and Febiger (1976).

11. Doughty, A.G. The evaluation of premedication in children. Proceedings of Royal Soc. Med. 52: 823-834 (1959).

12. DundeE, J.W., Moore, J. \& Nicholl, R.M. Studies of drugs given before anaesthesia: a method of preoperative assessment. Brit. J. Anaes. 34: 458-463 (1962).

13. Wassenar, W., Lancee, W.J., Galloon, S. \& GALE, G.O. The measurement of anxiety in the presurgical patient. Brit. J. Anaes. 49: 605-608 (1977).

14. Maguire, H.T., Webb, G.E., Rees, A.H. \& GaTTINELLE, J.B. Non invasive evaluation of cardiovascular effects of preoperative sedation in children. Canad. Anaes. Soc. J. 26: 29-33 (1979).

15. Levy, D.M. Psychic trauma of operations in children and note combat neurosis. Am. J. Dis. Child 69: 7-25 (1945)

16. JACKSON, K. Psychologic preparation as a method of reducing the emotional trauma of anesthesia in children. Anesthesiology 12: 293-300 (1951).

17. Francis, L. \& Cutler, R.P. Psychological preparation and pre-medication for pediatric anesthesia. Anesthesiology 18: 106-109 (1957).

18. Gilston, A. Sedative premedication? Anaesthesia 33: 374-375 (1978).

19. Freeman, A. \& Bachman, L. Pediatric anesthesia: an evaluation of preoperative medication. Anesth. Analges. Current Researches 38: 429-437 (1959).

20. KoRsCH, B.M. The child and the operating room. Anesthesiology 43: 251-257 (1975).

21. Meyers, E.F. \& Muravchick, S. Anesthesia induction technics in pediatric patients: a controlled study of behavioral consequences. Anesth. Analg. Current researches 56: 538-541 (1977).

22. Norris, W. Premedication. International Anesthesiology Clinics 9: 221-234 (1971).

23. STEWARD, D.J, \& Creighton, R.E. General anesthesia for minor surgery in healthy children. Current problems in Anesthesia and Critical Care Medicine Vol. 1, No. 5 (1977).

24. Doenicke, A., Krugler, J. \& Laub, M. Evaluation of recovery and "street fitness" by EEC and psychodiagnostic tests after anaesthesia. Canad. Anaes. Soc. J. 14: 567-583 (1967).

25. Smith, R.M. Pediatric anesthesia in perspective Anesth. Analg. 57: 634-646 (1978)

26. Barker, R.A. \& Nisbet, H.I.A. The objective measurement of sedation in children: a modified scoring system. Canad. Anaes. Soc. J. 20:599-606 (1973).

27. Schidt, K.F., Garfield, J.M. \& Korten, K. The pharmacology of agents used in out patient anesthesia. International Anesthesiology Clinics 14: 15-49 (1976).
28. Becker, L.D., Paulson, B.A., Miller, R.D, Severinghaus, J.W. \& Eger, E.I. Biphasic respiratory depression after fentanyl-droperidol or fentanyl alone used to supplement nitrous oxide anesthesia. Anesthesiology 44: 291 (1976).

29. MCQuay, H.J., Moore, R.A., Paterson, G.M.C. \& ADAMS, A.P. Plasma fentanyl concentrations and clinical observations during and after operation. Brit. J. Anaes. 51: 543-549 (1979).

30. Books, P.D. \& Chapman, D.H. Premedication in children undergoing day care surgery. Brit. J. Anaes. 5I: 1083-1087 (1979).

31. Simpson, J.E.P., GlynN, C.J., Cox, A.G. \& FolKARD, S. Comparative study of short term recovery of mental efficiency after anaesthesia. Brit. Med. J. 1: 1560-1562 (1976).

32. PaUL, A.K. Post anesthetic vomiting in children. Jour. Indian Med. Ass. 70: 29-31 (1978).

33. Brown, B.R. \& GEHA, D.G. Biotransformation of drugs used as premedication agents. Intern. Anesth. Clinics 13:61-77 (1975).

34. Forrest, W.H., Brown, C.R. \& Brown, B.W Subjective responses to six common preoperative medications. Anesthesiology 47: 241-247 (1977).

35. KORTTILA, K. Minor out patient anesthesia and driving. Mod. Probl. Pharmacopsych, 11: 91-98 (1976).

36. EgBert, L.D., Battit, G.E., Welch, C.E. \& BARTLETT, M.K. Reduction of post operative pain by encouragement and instruction of patients. New England J. of Med. 270: 825-827 (1964).

37. Leigh, J.M., Walker, J. \& Janaganathan, P. Effect of preoperative anesthetic visit on anxiety. Brit. Med. J. 2: 987-989 (1977).

38. Wolfer, J.A. \& Visintainer, M.A. Pre-hospital psychological preparation for tonsillectomy patients: effects on children's and parents adjustment. Pediatrics 64: 646-655 (1979).

39. SEWALL, K. Preoperative medication for children. Surgical clinics of North America. 50: 775-780 (1970).

40. Vernon, D.T.A. \& Bailey, W.C. Use of motion pictures in psychologic preparation of children for induction of anaesthesia. Anesthesiology 40:68-72 (1974).

4I. Conner, J,T. Sedation vs relief of anxiety. Anesthesiology 48: 300-301 (1978).

42. Gale, G. \& Galloon, S. Lorazepam as a premedication. Canad. Anaes. Soc. J. 23: 22-29 (1976).

43. NisBet, H.I.A. \& NorRIS, W. Ojective measurement of sedation: a simple scoring system. Brit. J. Anaes. 35: 618-623 (1963).

44. STEward, D.J. Experiences with an out patient anesthesia service for children. Anesth. Analg. Current Researches 52: 877-880 (1973).

45. SChulman, J.L., Foley, J.M., Vernon, D.T.A \& ALLAN, D. A study of the effect of the mother's presence during anesthesia induction. Pediatrics 39: 111-114(1967).

46. Da venport, H.T., Shah, C.P. \& Robinson, G.C. Day surgery for children. Canad. Med. Ass. J. 105: 498-501 (1971).

47. Stewart, D.J. Out patient pediatric anesthesia. Anesthesiology 43: 268-276 (1975).

48. Vernon, D. T.A., Foley, J.M. \& SiPOWicz, R. R The psychological responses of children to hos- 
pitalisation and illness. A review of the literature. Springfield, Ill. Thomas (1965).

49. Oosterlee, J. \& Dudley, H.A.F. Surgery in out patients. Brit. Med. J. I: 1459-1460 (1979).

50. Urbach, G.M. \& Edelist, G. An evaluation of the anaesthetic techniques used in an out patient unit. Canad. Anaes. Soc. J. 24: 401-407 (1977).

51. Brindle, G.F. \& Soliman, M.G. Anaesthetic complications in surgical out patients. Canad. Anacs. Soc. J. 22: 613-619(1975).

52. Sмith, B.L. \& Young, P.N. Day stay anesthesia: follow up of day patients undergoing dental opera. tions under general anesthesia with tracheal intubation. Anesthesia 31: 181-189(1976).

53. KREIENBÜHL, G. Subjective complaints of out patients following halothane and enflurane anaesthesia. Anaesthesist 27: 533-537 (1978).

54. KoRtTILA, K. \& LinNoïlA, M. Recovery and simulated driving after IV anesthesia with thiopental, methohexital, propranadid or alphadione. Anesthesiology 43:283-291 (1975).

\section{RÉSUMÉ}

Considérant qu'une prémédication anesthésique a comme but premier de rendre plus agréable et douce l'anesthésie dans son ensemble, cette étude prospective à double insu se veut une critique de trois types de prémédication comparativement a un placebo quant a leur valeur pour atteindre le but visé. L'étude a aussi comme but d'inventorier les complications (pris dans son sens le plus large) autant physiques que psychologiques qui surviennent durant l'anesthésie et dans le court et moyen terme du post-opératoire et d'en comparer l'incidence selon que les patients aient recu un médicament actif ou le placebo.

Pour ce, 159 patients agés de un à 12 ans furent sélectionnés et distribués au hazard entre quatre groupes thérapeutiques (hydroxyzine $0.5 \mathrm{mg} \cdot \mathrm{kg}^{-1}$, promethazine $0.5 \mathrm{mg} \cdot \mathrm{kg}^{-1}$, diazepan $0.1 \mathrm{mg} \cdot \mathrm{kg}^{-1}$ et un placebo) qui reçurent tous la prémédication per os sous forme d'élixir environ 60 minutes avant l'induction de l'anesthésie. De ces 159 patients, 137 dossiers sont complets, les parents ayant retourné leur partie de l'évaluation consernant l'évolution à la maison. Cette etude nous a permis d'obtenir les résultats suivants:

- il n'existe aucune différence statistiquement significative entre les quatre groupes thérapeutiques et la qualité de l'induction anaesthésique même si l'hydroxyzine donnait des patients plus calmes que le placebo a l'arrivée en salle d'opération.

- l'incidence des complications par et post opératoire et leur severite sont les même dans les quatre groupes et aucun n'a presenté d'avantage de réactions psychologiques que l'autre a la maison (insomnie, énurésie, perte de propreté diurne, agressivité accrue, identification à l'agresseur, dépression psycho-motrice, besoins affectifs accnus et crainte d'être puni). De plus le groupe de patient dont l'induction anesthésique a été la plus orageuse n'a pas montré d'incidence accrue de réactions psychologiques post-operatoire.

- les délais observés pour les différents stades d'éveil sont les mêmes dans les quatre groupes thérapeutiques, ainsi que dans le groupe à induction orageuse vs celui avec une induction plus douce.

- finalement nous avons observé un taux de satisfaction des anesthésistes face a la prémédication recue d'environ 80 pour cent dans les quatre groupes et un taux de satisfaction de 90 pour cent chez les parents face a l'hospitalisation dans son ensemble.

Nous concluons de cette étude que la population pédiatrique devant subie une anesthésie et une chirurgie en externe ne devrait pas reçevoir de prémédication pharmacologique (ormis de l'atropine IV a l'induction); non pas à cause de risques accrus avec l'utilisation de prémédica. tion, mais à cause de l'absence de bénéfice encouru dans cette étude. 